\title{
PRELIMINARY PHYTOCHEMICAL SCREENING AND IN VITRO ANTI-MICROBIAL ACTIVITY OF ETHANOLIC EXTRACT OF DELONIX REGIA (HOOK) RAF. BARK (FAMILY-LEGUMINOSAE)
}

\author{
BIKASH GUPTA*, BISWAJIT DASH, SUJATA PAUL, ADITYA BORA \\ Girijananda Chowdhury Institute of Pharmaceutical Science Azara, Guwahati, India \\ Email: bikashgupta1610@gmail.com
}

Received: 21 Apr 2018, Revised and Accepted: 10 Jun 2018

\begin{abstract}
Objective: To estimate the anti-microbial activity of ethanolic extract of Delonix regia (Hook.) Raf (family-Leguminosae) in association with phytochemical analysis.

Methods: The ethanolic extract of the bark of Delonix regia (Hook.) Raf was prepared and investigate for phytochemical constituents using standard methods. Antimicrobial activity of ethanolic extract of were carried out against one Gram positive bacteria= Staphylococcus aureus and one Gram negative bacteria= Escherichia coli. The anti-fungal activity of the plant extract was evaluated on Candida albicans. The testing was done by the disc diffusion method. A zone of inhibition of ethanolic extract was compared with that of standard Amikacin for anti-bacterial activities and Fluconazole for anti-fungal activity.

Results: The present investigation shows the phytochemical analysis, antimicrobial activity of the ethanolic extract of the bark of Delonix regia (Hook.) Raf. Various phytochemical analyses revealed the presence of alkaloids, anthraquinone, phenol, terpenes, cardenolides, phlobatannins, tannin, chalcones, steroids. The anti-microbial activity of the ethanolic extract of the plant showed significant results against all three of the test organisms.
\end{abstract}

Conclusion: The present study concluded that ethanolic extract of the bark of Delonix regia (Hook.) Raf contains the high existence of phytochemicals. The ethanolic extract of the plant was found to possess promising antimicrobial activity when compared with the standards.

Keywords: Delonix regia, Anti-microbial, Agar disc diffusion method, Zone of Inhibition

(C) 2018 The Authors. Published by Innovare Academic Sciences Pvt Ltd. This is an open access article under the CC BY license (http://creativecommons.org/licenses/by/4.0/) DOI: http://dx.doi.org/10.22159/ijcpr.2018v10i4.28460

\section{INTRODUCTION}

In developing countries, the bacterial infections are one of the mojor issues. Bacteria such as Gram+ve like Staphylococcus aureus are responsible for the food poisoning, septicemia, postoperative wound infection, etc. Whereas, Gram-ve bacteria like Escherichia coli cause urinary tract infection, septicemia [1].

Due to a complicated interaction between the pathogen, the host and the environment of infectious diseases are arises. The invention of antibiotics and their successive use had eliminated the disease that once obstacle the people. Still, use of antibiotics is going through an emergency due to the development of resistance of the diseasecausing organism. Antibacterial antibiotics such as Methicillin has become resistant to Staphylococcus aureus. Other examples are vancomycin-resistant enterococci, multidrug-resistant tuberculosis, and others. In addition, these pathogen have the capacity to communicate the resistance gene and generate a serious complication in the field of medicine. Before the discovery of antibiotics as remedies, the plant has been used for the treatment of a number of diseases. They are effective in the treatment of communicable diseases with fewer side effects that are frequently occur with synthetic antimicrobial agents [2].

Delonix regia is a flowering plant occur in all over Asia it belongs to the family Leguminosae. This plant was reported to have anti-oxidant, anti-arthritic, anti-inflamatory, analgesic, anti-diarrhoeal, anti-ulcer activity. This plant having the following characteristics [3]:

Table 1: Morphological character of Delonix regia plant

\begin{tabular}{ll}
\hline Height & $35-40$ feet \\
Leaf arrangement & Biparipinnate, slightly hair, alternate, light green \\
Seeds & Olive brown or black in color. \\
Flowers & Orange-red \\
Fruits & Elongate and oblong \\
Bark & Vertical thick \\
Root & Much deep with paste resistance \\
Leaf shape & Oblong and evergreen type of leaf \\
\hline
\end{tabular}

Around the world, drugs play an essential role in healthcare services. The rational design of novel drugs from conventional drugs offers new anticipation in new healthcare system. Due to less adverse and side effect nowadays people choose plant-based medicines over synthetic medication for the therapy of various diseases. Although the presence of effective synthetic drugs, use of medicinal plants for maintaining human health has gained a lot of importance in the present period. As per ayurvedic system of medicine, the Delonix regia tree balances pitta (fire and water) and vata (earth and air) hence widely used in ayurvedic, unani and in homeopathic medicines.

The researcher has reported the anti-microbial activity of many plants. The medicinal plant are rich in secondary metabolites such as alkaloids, terpenoids, tannins, flavonoids, glycoside which can be attributed to anti-microbial activity. [4]. Thus, an effort was made for the separation of ethanolic extract and make an investigation of them for anti-microbial activity. 


\section{MATERIALS AND METHODS}

\section{Collection of plant materials}

Delonix regia (Hook.) Raf was collected from Bokajan, Karbi Anglong, Assam, India. The plant specimen was authenticated by Dr. G. C. Sarma, Curator, Department of Botany, Gauhati University, Guwahati, Assam. The voucher specimen has been stored in the Herbarium of the Department of Botany, Gauhati University with voucher no Acc. No.-18379 dated 23-11-2017, for future reference.

\section{Chemicals and reagents}

Petroleum Ether (PE), Ethanol (ET), dimethyl sulfoxide (DMSO), hydrochloric acid, Dragondorff reagent, Mayer's reagent, Wagner's reagent, Benedict's reagent, sulfuric acid, lead acetate, Molisch's reagent, Fehling solution A and B, sodium citrate, copper sulphate, ferric chloride, sodium hydroxide, glacial acetic acid, benzene, chloroform, ammonia, nitric acid, potassium nitrite, gelatine, Beef extract, Peptone and agar. All the chemicals and solvents used were of standard analytical grades.

\section{Preparation of the plant extract}

The mature and immature bark of plant was collected, washed under running tap water to remove dust, shade dried and then kept at tray drier at $37{ }^{\circ} \mathrm{C}$ for $48 \mathrm{~h}$. Using an electric grinder the dried plant materials were grinded to a fine powder. And it was defatted with Petroleum Ether by using soxhlet apparatus (Borosil, India) and then extracted with Ethanol in the order of their increasing polarity by maceration process until it got to be distinctly dry as indicated by the standard techniques. The solution was filtered using Whatman no. 4 filter paper and the filtrate was concentrated to a semi-solid residue in a rotary vacuum evaporator and put away in the refrigerator for further anti-microbial analysis [5]. The extract acquired was weighed and the rate yield was figured as far as the dried weight of the plant material utilizing the equation:

Calculation of \% Yield $=$ (Dry weight of the extract/Dry weight of leaf sample) $\mathrm{x} 100$.

\section{Phytochemical screening}

The plant extract was tested for the presence of alkaloids, saponin, flavonoids, phenol, carbohydrates, proteins and amino acids, cardiac glycosides, steroids, anthraquinone and terpenoids using the the standard procedure $[6,7]$.

\section{Alkaloids}

Reagent: Dragendorff's reagent (Potassium iodide+Bismuth nitrate).

Procedure: $0.5 \mathrm{~g}$ each of the dried ethanolic extracts were weighed and re-extracted with $5 \mathrm{ml}$ of $5 \%$ hydrochloric acid. The hydrochloric acid extract was filtered. Few drops of Dragendorff's reagent were added to $2.5 \mathrm{ml}$ of the filtrate.

Result: A reddish brown color and turbidity with the reagent indicates the presence of alkaloid.

\section{Tannins}

Reagent: Ferric chloride.

Procedure: $0.5 \mathrm{~g}$ of the dried ethanolic extract was stirred with $10 \mathrm{ml}$ of distilled water, filtered and ferric chloride was added to the filtrate.

Result: Appearance of blue or blue-black, green or blue-green coloration indicates the presence of tannin.

\section{Saponins}

Reagent: $1 \%$ gelatin solution.

Procedure: To the extract, $1 \%$ gelatin solution containing sodium chloride was added.

Result: Formation of white precipitate indicates the presence of tannins.

\section{Flavonoids}

Reagent: Lead acetate solution.
Procedure: Extract was treated with few drops of lead acetate solution.

Result: Formation of yellow colour precipitate indicates the presence of flavonoids.

\section{Anthraquinones}

Reagent: Benzene, ammonium hydroxide.

Procedure: $0.5 \mathrm{~g}$ of dried ethanolic extract was shaken with $10 \mathrm{ml}$ of benzene and then filtered, followed by the addition of ammonium hydroxide to the filtrate.

Result: Formation of a pink, red or violet coloration in the ammonical phase indicates the presence of anthraquinone.

\section{Phenols}

Reagent: Ferric chloride.

Procedure: $0.5 \mathrm{~g}$ of the ethanolic extract was first extracted with ethyl acetate and the extract was filtered.

Result: Development of a blue-black or brown coloration on the addition of ferric chloride indicate the presence of phenol.

\section{Phlobatannins}

Reagent: $1 \%$ hydrochloric acid

Procedure: $0.5 \mathrm{~g}$ of ethanolic extract was boiled with $1 \%$ hydrochloric acid

Result: Formation of red precipitate confirms the presence of phlobatannins.

\section{Chalcones}

Reagent: Ammonia solution

Procedure: $2 \mathrm{ml}$ of ammonia solution was added to $5 \mathrm{ml}$ of ethanolic extract.

Result: Formation of a reddish colour confirms the presence of chalcone.

\section{Steroids}

Reagent: Acetic anhydride, sulphuric acid.

Procedure: $2 \mathrm{ml}$ of acetic anhydride was added to $0.5 \mathrm{~g}$ of ethanolic extract and cooled in ice. $1 \mathrm{ml}$ of acetic anhydride, sulphuric acid, and chloroform sulphuric acid was carefully added three times to obtain a colour change from violet to blue and blue to finally green.

Result: Color change from violet to blue and blue to finally green indicates the presence of steroids.

\section{Terpenes}

Reagent: Acetic anhydride, sulphuric acid, chloroform.

Procedure: Mixture of $10 \mathrm{ml}$ of acetic anhydride, concentrated sulfuric acid and $20 \mathrm{ml}$ chloroform was added to $0.5 \mathrm{~g}$ of ethanolic extract.

Result: Formation of bluish-green precipitate indicate the presence of terpenes.

\section{Cardenolides}

Reagent: Glacial acetic acid, ferric chloride, sulphuric acid.

Procedure: $0.5 \mathrm{~g}$ of ethanolic extract was added to $2 \mathrm{ml}$ of glacial acetic acid containing one drop of ferric chloride solution. $1 \mathrm{ml}$ of concentrated sulphuric acid was added to underlay it.

Result: A brown ring precipitate obtained indicates the presence of cardenolides.

\section{Glycosides}

Reagent: Chloroform, sulphuric acid. 
Procedure: $0.5 \mathrm{~g}$ of each powdered sample was dissolved in $2 \mathrm{ml}$ of chloroform. $10 \mathrm{ml}$ of concentrated sulphuric acid was added carefully to form a lower layer.
Result: A reddish-brown color at the interphase indicates the presence of glycoside.

Table 2: Microorganisms used for anti-microbial activity

\begin{tabular}{lllll}
\hline Bacterial strain & & & & Fungal strain \\
\hline Gram positive organism & MTCC No. & Gram negative organism & MTCC No. & Name \\
Staphylococcus aureus & MTCC3159 & Escherichia coli & MTCC1651 & Candida albicans \\
\hline
\end{tabular}

\section{Microbial strains}

The strain maintained in sterile conditions and grown on Nutrient Agar (NA) for bacteria and Sabourand dextrose agar (SDA) for fungi in the Microbiology Laboratory, Girijananda Chowdhury Institute of Pharmaceutical Science, Azara, Guwahati, India.

\section{Preparation of extract solution}

On the day of experimentation for in vitro anti-microbial activity study, dissolve 0.3 grams of the crude extract in $0.1 \mathrm{ml}(100 \mu \mathrm{l})$ of $100 \%$ dimethylsulfoxide (DMSO) and volume was made up to $1 \mathrm{ml}$ $(1000 \mu \mathrm{l})$ with distilled water from that different concentration of the suspension was prepared for the anti-microbial sensitivity test.

\section{Anti-microbial activity}

\section{Anti-bacterial assay}

The anti-microbial activity of the plant extract was carried out by the paper disc diffusion method. Plant extract was prepared by dissolving in DMSO and sonicated and filtered (Stock: $1 \mathrm{mg} / \mathrm{ml}$ DMSO). A suspension of testing microorganisms was spread on an adequate amount of Muller Hinton Agar medium into sterile plates and allowed to solidify in the refrigerator under aseptic conditions. The plant extract of different concentration like 25, 50, and $100 \mu \mathrm{l}$ was impregnated with sterile $5 \mathrm{~mm}$ diameter of whatman no4 paper discs. The plates were then subsequently incubated at $37^{\circ} \mathrm{C}$ for $24 \mathrm{~h}$. After incubation, all the plates were observed for zones of inhibition and the diameter of these zones were measured in millimeters. All the procedure was performed under sterile conditions. Amikacin (30 $\mu \mathrm{l})$ served as positive controls [8].

\section{Anti-fungal assay}

The antifungal activity of plant extract was tested by the paper disc diffusion method. The sabouraud dextrose agar plates were inoculated with Candida albicans by point inoculation. The filter disc ( $5 \mathrm{~mm}$ in diameter) impregnated with a different concentration of plant extracts like 25, 50, and $100 \mu \mathrm{l}$ and were placed on the test organisms seeded plates. Fluconazole standard disc $10 \mu \mathrm{g} / \mathrm{disc}$ was used for the anti-fungal assay. The activity was performed after $3 \times 24 \mathrm{~h}$ of incubation at $28^{\circ} \mathrm{C}$. The inhibition zones were measured in millimetres after overnight incubation and compared with that of standard antifungal (Fluconazole) $(10 \mu \mathrm{l})$ which was used as positive control. All tests were performed under sterile conditions [9].

\section{RESULTS}

The present study shows the phytochemical screening, antimicrobial activity of the ethanolic extract of the plant Delonix regia. The yield $\%$ of the extraction of the ethanol was $4.55 \%$.

\section{Phytochemical screening}

Table 3 presents the qualitative phytochemical screening of plant extract shows the presence of various chemical constituents like alkaloid, tannin, anthraquinone, phenols, phlorotannins, chalcones, steroids, terpenes, cardenolides.

\section{Anti-microbial activity}

Table 4 presents the in vitro antimicrobial activity of the ethanolic extract of Delonix regia under different concentration with the standard.

The ethanolic extract of the Delonix regia barks exhibits anti-microbial activity against both grams positive and gram negative bacteria.

Table 3: Qualitative phytochemical screening of ethanolic extract of the bark of Delonix regia

\begin{tabular}{|c|c|c|c|}
\hline S. No. & Phytochemical test & Observation & Result \\
\hline 1 & Alkaloid & Reddish brown colour and turbidity & ++ \\
\hline 2 & Anthraquinones & Formation of a pink colour & ++ \\
\hline 3 & Phenols & Formation of a brown colour & ++ \\
\hline 4 & Terpenes & Formation of bluish-green precipitate & ++ \\
\hline 5 & Cardenolides & Formation of brown ring precipitate & ++ \\
\hline 6 & Phlobatannin & Formation of red precipitate & + \\
\hline 7 & Tannin & Formation of blue or blue-black & + \\
\hline 8 & Chalcones & Formation of a reddish color & + \\
\hline 9 & Steroids & Colour change from violet to blue and blue to finally green & + \\
\hline 10 & Saponin & White precipitate not formed & - \\
\hline 11 & Flavonin & Yellow colour precipitate not formed & - \\
\hline 12 & Glycoside & Reddish-brown colour not formed at the interphase & - \\
\hline
\end{tabular}

$++=$ Present in a moderate amount, $+=$ Present in a trace amount,-= Completelt absent

Table 4: Antimicrobial activity of bark ethanolic extract Delonix regia observed aginst the growth of some plant pathogenic bacteria using disc diffusion method

\begin{tabular}{llll}
\hline \multirow{2}{*}{$\begin{array}{l}\text { Name of the compounds } \\
\text { with concentration }\end{array}$} & \multicolumn{2}{l}{ Anti-bacterial activity diameter of zone of inhibition(mm) } & Anti-fungal activity diameter of zone of inhibition (mm) \\
\cline { 2 - 4 } & Escherichia coli & Staphyllococcus aureus & Candida albicans \\
\hline Amikacin $(30 \mu \mathrm{l})$ & 28.34 & 25.14 & --- \\
Fluconazole $(10 \mu \mathrm{l})$ & --- & -- & 14.35 \\
Plant Extract $(25 \mu \mathrm{l})$ & 16.22 & 12.21 & 16.42 \\
Plant Extract $(50 \mu \mathrm{l})$ & 18.15 & 14.18 & 21.18 \\
Plant Extract $(100 \mu \mathrm{l})$ & 22.61 & 18.32 & 2 \\
\hline
\end{tabular}

Zone including $5 \mathrm{~mm}$ of paper diameter 


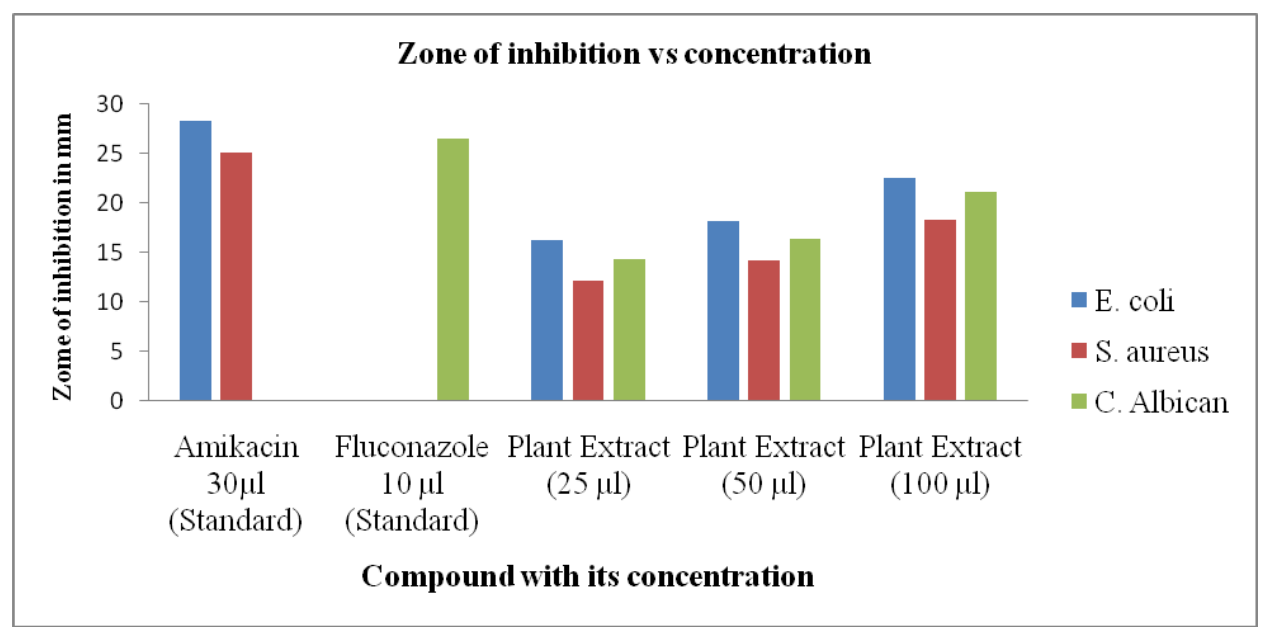

Fig. 1: Zone of inhibition vs concentration

\section{RESULTS AND DISCUSSION}

\section{Phytochemical analysis}

The phytochemical test with the ethanolic extracts of the dried Delonix regia bark manifest the presence of various phytoconstituent like alkaloids, anthraquinone, phenol, terpenes, cardenolides, phlobatannin, tannin, chalcones, steroids are given in (table 3).

\section{Anti-bacterial and anti-fungal activity}

Generally, it was well known that the plant extract is rich in the anti-microbial compound. The extract of Delonix regia bark were screened in vitro by an agar well diffusion method using Amikacin as the standard for anti-bacterial activity and Fluconazole as standard for anti-fungal activity against selected bacterial and fungal strains.

The result for ethanolic extracts of Delonix regia bark was shown in table 4.

Among the various concentrations of the ethanolic extract. Concentration $25 \mu$ l exhibit a minimum zone of inhibition whereas $100 \mu \mathrm{l}$ exhibit maximum zone of inhibition against the bacterial strain of Escherichia coli and Staphyllococcus aureus.

Whereas, in the case of fungal strain concentration $25 \mu \mathrm{l}$ exhibit a minimum zone of inhibition whereas $100 \mu \mathrm{l}$ exhibit maximum zone of inhibition against the fungal strain of Candida albicans.

\section{CONCLUSION}

The result confirms the significant antimicrobial activity of the extract Delonix regia (Hook.) Raf. The plant extracts have great potential as antimicrobial compound against disease-causing organisms.

In this study, the anti-microbial activity of the bark of Delonix regia (Hook.) Raf. was evaluated by using the disk diffusion method. The microorganisms select to be studied were Gram positive Staphyllococcus aureus and Gram negative Escherichia coli and fungus like Candida albicans. It is anticipated that this study would guide to the creation of some compounds that could be used to develop new and more powerful anti-microbial drugs of natural origin.

\section{ACKNOWLEDGEMENT}

The authors thankful to Mr. Bishwajit Dash, Assistant Professor Department of Pharmaceutical Chemistry, Girijananda Chowdhury
Institute of Pharmaceutical Science Azara, Guwahati, India for his support and guidance provided during this work and Head of the Department, Guwahati university for authentication of the plant specimen and Principal and Department of Microbiology, Girijananda Chowdhury Institute of Pharmaceutical Science, Azara, Guwahati for conveying this exploration work.

\section{AUTHORS CONTRIBUTIONS}

All the author have contributed equally

\section{CONFLICT OF INTERESTS}

There was no conflict of interest

\section{REFERENCES}

1. Hussain M, Shahid MR, Khalid HJ, Khan MRU, Aziz A, Majeed A. In vitro comparative study of antimicrobial activity of whole plant and root's bark of Delonix regia (Bojer Ex. Hook). Int J Pharma Sci 2014;4:736-41.

2. Vivek MN, Swamy SHC, Manasa M, Kambar Y, Chaithra M, Mallikarjun $\mathrm{N}$, et al. Antioxidant activity of leaf and flower extract of Caesalpinia pulcherrima, Delonix regia and Peltaphorum ferrugineum. JAPS 2013;3:64-71.

3. Patil DD, Mhaske DK, Machindra AP, Wadhawa GC. Antibacterial and antioxidant, the anti-inflammatory study of leaves and root Delonix regia. Int J Pharm Chem Sci 2014;3:131-5

4. Nagarajan SS, Muthusamy P, Ramalingam R. An overview-royal poinciana. J Pharmacogn Phytochem 2015;7:232-8.

5. Kurian S, Josekumar VS. Phytochemical screening, antimicrobial activity and brine shrimp lethality bioassay of different extracts of Alysicarpus vaginalis var. nummularifolius (DC.) MIQ. (family: fabaceae). Int J Pharm Sci 2017;9:1-6.

6. Tiwari P, Kumar B, Kaur M, Kaur G, Kaur H. Phytochemical screening and extraction: a review. Int Pharm Sci 2011;1:98-106.

7. Ibironke AA, Sarah ON, Adewale A. Anti-microbial activity and phytochemical screening of five selected seeds from Nigeria. Int J Biomed Pharm Sci 2010;4:104-6.

8. Chetan PS, Murugananthan G, Komaleeswari K. Evaluation of antimicrobial activity of methanolic extract fractions of Delonix elata bark. Int J Res Ayurveda Pharm 2012;3:425-7.

9. Gayathri G, Saraswathy A, Vijayalakshmi K. Anti-microbial activity of medicinal plant Bauhinia variegata Linn. Int J Pharma Bio Sci 2011;1:400-8. 